\title{
Pengaruh Model Pembelajaran Probing-Prompting Berbantuan Media Sederhana Terhadap Hasil Belajar IPA
}

\author{
Sherina Surya Sahayu1*, I Nyoman Jampel2, I Nyoman Laba Jayanta ${ }^{3}$ \\ 1,2,3 Jurusan Pendidikan Guru Sekolah Dasar (PGSD), Universitas Pendidikan Ganesha, Singaraja, Indonesia.
}

\section{A R T I C L E I N F O}

Article history:

Received 20 May 2018

Received in revised form

07 June 2018

Accepted 10 July 2018

Available online 22 August 2018

Kata Kunci:

Probing-Prompting, Hasil

Belajar, IPA

Keywords:

Probing-Prompting,

Learning Outcomes, Science

\begin{abstract}
A B S T R A K
Penelitian ini bertujuan untuk mengetahui pengaruh hasil belajar antara kelompok siswa yang mendapat perlakuan model pembelajaran probing-prompting berbantuan media sederhana dengan kelompok siswa yang tidak mendapat perlakuan model pembelajaran probingprompting berbantuan media sederhana pada mata pelajaran IPA. Penelitian ini termasuk penelitian eksperimen semu yang menggunakan desain non-equivalent post-test only control group design. Populasi penelitian ini adalah seluruh kelas III SDN di Gugus III Kecamatan Banjar. Sampel penelitian adalah SDN 3 Dencarik yang berjumlah 20 orang sebagai kelompok eksperimen dan SDN 2 Dencarik yang berjumlah 25 orang sebagai kelompok kontrol. Metode pengumpulan data menggunakan metode tes dengan instrument tes pilihan ganda hasil belajar IPA. Analisis hipotesis menggunakan uji-t berbantuan SPSS 20. Hasil penelitian menunjukkan bahwa terdapat pengaruh hasil belajar pada kelompok siswa yang diberikan perlakuan model pembelajaran probing-prompting berbantuan media sederhana dengan
\end{abstract} kelompok siswa yang tidak diberikan perlakuan model pembelajaran probing-prompting berbantuan media sederhana dalam pembelajaran IPA. Jadi, model pembelajaran probing-prompting berbantuan media sederhana berpengaruh terhadap hasil belajar IPA pada siswa kelas III di Gugus III Kecamatan Banjar Kabupaten Buleleng Tahun Pelajaran 2017/2018. Saran dari penelitian ini adalah agar dapat digunakan sebagai pedoman dalam penelitian lebih lanjut tentang model pembelajaran probingprompting berbantuan media sederhana khususnya pada IPA.

\section{A B S T RA C T}

This study aims at determining the differences in learning outcomes between groups of students who received treatment of probing-prompting models with simple media assisted with groups of students who did not receive treatment of probing-prompting model with simple media assisted on science subjects. This study is quasi-experimental research using non-equivalent design post-test only control group design. The population of this study is the entire class III SDN in Gugus III Banjar District. The sample of this research is SDN 3 Dencarik which amounted to 20 people as experiment group and SDN 2 Dencarik which amounted to 25 people as control group. The methods of data collection are using the test method that was done through multiple choice instrument test of science learning outcomes. The hyphotesis analysis was done by using t-test asissted with SPSS 20. The results showed that there were differences of learning outcomes in the group of students who were given the treatment of probing-prompting model with simple media assisted with the group of students who were not given treatment of probing-prompting model with simple media-assisted learning in the science lessonThus, the probing-prompting learning model with simple media assisted affects the learning outcomes of Science subject on grade III students in Gugus III Banjar District, Buleleng Regency, Year 2017/2018. The suggestion of this research is that it can be used as a guide in further research about simple media assisted probing-prompting learning model especially on IPA. 


\section{Pendahuluan}

Pendidikan merupakan kumpulan dari semua proses yang memungkinkan seseorang mampu mengembangkan seluruh kemampuan (potensi) yang dimilikinya, sikap-sikap dan bentuk-bentuk perilaku yang bernilai positif di masyarakat tempat individu yang bersangkutan berada (Sukardjo \& Komarudin, 2009). Pendidikan adalah sebuah wahana untuk meningkatkan dan mengembangkan kualitas manusia menjadi manusia ideal (. Menurut UU No. 20 Tahun 2003 Pasal 1 Ayat 1 tentang Sistem Pendidikan Nasional (2003:1) menyatakan bahwa pendidikan adalah usaha sadar dan terencana untuk mewujudkan suasana belajar dan proses pembelajaran agar peserta didik secara aktif mengembangkan potensi dirinya untuk memiliki kekuatan spiritual keagamaan, pengendalian diri, kepribadian, kecerdasan, akhlak mulia, serta keterampilan yang diperlukan dirinya, masyarakat, bangsa dan negara. Dengan demikian pendidikan saat ini diharapkan agar dapat mengembangkan seluruh kemampuan (potensi) yang dimiliki peserta didik secara aktif didalam proses pembelajaran khususnya di sekolah dasar. Pendidikan lahir dari pergaulan antar orang dewasa dan orang yang belum dewasa dalam suatu kesatuan hidup (Artawan, 2017).

Pembelajaran di sekolah dasar merupakan sebuah proses interaksi antara berbagai potensi diri siswa (fisik, nonfisik, emosi, dan intelektual). Interaksi siswa dengan guru, siswa dengan siswa lainnya, serta lingkungan dengan konsep dan fakta, interaksi dari berbagai stimulus dengan berbagai respons terarah untuk melahirkan perubahan (Susanto, 2014). Sejalan dengan hal tersebut Winataputra (dalam Ngalimun, 2016) pembelajaran merupakan sarana untuk memungkinkan terjadinya proses belajar dalam arti perubahan perilaku individu melalui proses mengalami sesuatu yang diciptakan dalam rancangan proses pembelajaran. Namun yang berlangsung saat ini pembelajaran masih berpusat pada guru (teacher centered) sehingga kurang mendorong siswa untuk mengembangkan kemampuan berfikir dan peran aktif siswa dalam pembelajaran. Akibatnya siswa kurang antusias dalam mengikuti kegiatan pembelajaran di kelas sehingga berdampak pada rendahnya hasil belajar siswa

Menurut Piaget (dalam Sudana, dkk, 2016) tahap perkembangan siswa kelas III sekolah dasar masih berada pada tahap operasional konkrit yaitu mereka berpikir atas dasar pengalaman konkrit/nyata serta belum bisa berpikir abstrak. Kemampuan untuk berpikir sedikit abstrak harus didahului dengan pengalaman konkrit/nyata. Kemudian, barulah akhirnya mereka mulai dapat berpikir abstrak yang sederhana. Sejalan dengan hakikat IPA (Sudana, dkk, 2016) menyatakan bahwa hakikat IPA terdiri dari IPA sebagai produk dan IPA sebagai proses. IPA sebagai produk merupakan kumpulan hasil kegiatan emperik dan kegiatan analitik yang dilakukan para ilmuwan selama berabad-abad. Sedangkan, IPA sebagai proses, yaitu untuk menggali dan memahami pengetahuan tentang alam. Karena IPA merupakan kumpulan fakta dan konsep, maka IPA membutuhkan proses dalam menentukan fakta dan teori yang akan digeneralisasi oleh ilmuan. Jika ditelaah lebih lanjut maka fakta-fakta merupakan hasil dari kegiatan empirik (berpikir atas dasar pengalaman nyata) dalam sains sedangkan konsep-konsep, prinsip-prinsip, dan teori-teori dalam sains merupakan hasil dari kegiatan analitik (berpikir abstrak sederhana). IPA tidak hanya merupakan kumpulan pengetahuan atau fakta-fakta tapi juga suatu cara kerja, cara berpikir dan cara memecahkan masalah. Maka dari itu, siswa kelas III yang masih berada pada tahap oprasional konkrit masih membutuhkan benda-benda untuk menolong pengembangan kemampuan intelektualnya.

Menurut Bundu (dalam Riastini, 2016) sains bisa diterjemahkan sebagai Ilmu Pengetahuan Alam yang berasal dari kata natural science. Natural artinya alamiah dan berhubungan dengan alam. Science artinya ilmu pengetahuan. Jadi, secara harafiah, sains dapat disebut sebagai ilmu pengetahuan tentang alam atau ilmu pengetahuan yang mempelajari peristiwa-peristiwa yang terjadi di alam. Dalam pembelajaran IPA di SD seorang guru dituntut untuk dapat mengajak siswa memanfaatkan alam sekitar sebagai sumber belajar. Sebab, alam sekitar merupakan sumber belajar yang paling otentik dan tidak akan habis digunakan.

Berdasarkan hasil observasi yang dilakukan di Kelas III SDN Gugus III Kec.Banjar Kab. Buleleng terlihat, peran aktif siswa dalam mengikuti pelajaran IPA sangatlah kurang karena ada banyak siswa teralihkan konsentrasi serta perhatiannya keluar kelas dan bermain dengan teman sebangkunya. Pada saat proses pembelajaran IPA guru enggan untuk menggunakan media pembelajaran, hal ini disebabkan sekolah tidak memiliki media yang layak untuk digunakan serta walaupun ada bantuan dari pemerintah berupa media pembelajaran yang baru guru belum bisa mengoperasikan dan takut menggunakannya karena harus bertanggung jawab penuh apabila media pembelajaran itu rusak atau hilang. Disamping itu, guru juga kurang memberi kesempatan kepada siswa untuk bertanya, memberikan pendapat, serta menjelaskan pendapatnya secara logis saat proses pembelajaran. Padahal pelajaran IPA sangatlah penting dalam kehidupan sehari-hari sebab berkaitan dengan lingkungan sekitar yang ada dalam kehidupan anak. Meskipun alam dapat dilihat secara langsung namun masih banyak siswa yang mengalami kesulitan memahami pembelajaran IPA sehingga mengakibatkan rendahnya hasil belajar siswa. 
Hasil belajar IPA siswa kelas III di SD Gugus III Kecamatan Banjar sebagian besar belum mencapai KKM, hal ini terbukti dari nilai Ujian Akhir Semeter I dengan nilai KKM pada SD di Gusus III Kec.Banjar Kab. Banyaknya siswa yang mengulang atau remidi dengan rata-rata rentangan 38,89\% - 73,33\% per kelasnya, artinya terdapat 4 sampai 17 siswa yang mengulang per kelasnya dalam mengikuti pelajaran IPA pada SD di Gugus III Kecamatan Banjar Kabupaten Buleleng.

Oleh sebab itu, untuk meminimalkan perolehan hasil belajar yang di bawah KKM atau mengulang/remidi, perlu dilakukan upaya alternatif dalam pembelajaran oleh guru dengan melibatkan siswa secara aktif, memperkaya pengalaman belajar siswa melalui pengunaan model, metode, dan strategi pembelajaran dengan tepat. Pemilihan model, metode dan strategi pembelajaran haruslah yang dapat membuat siswa aktif dan antusias dalam mengikuti pembelajaran serta dapat menimbulkan suasana pembelajaran yang menyenangkan bagi siswa. Kini guru hendaknya membenahi diri agar dapat memancing keaktifan siswa khususnya dalam pelajaran Ilmu Pengetahuan Alam. Salah satu model pembelajaran yang berpusat pada siswa dan menuntut siswa untuk terlibat aktif ialah model probingprompting.

Model pembelajaran probing-prompting merupakan suatu model pembelajaran dengan cara guru menyajikan serangkaian pertanyaan yang sifatnya menuntun dan menggali sehingga terjadi proses berpikir yang mengkaitkan pengetahuan dan pengalaman siswa dengan pengetahuan baru yang sedang di pelajari (Ngalimun, 2016). Model pembelajaran Discovery Learning adalah suatu metode pembelajaran yang membimbing siswa untuk menemukan hal-hal yang baru bagi siswa berupa konsep, rumus, pola, dan sejenisnya (Hanggara, 2015). Dengan menggunakan model pembelajaran ini proses tanya jawab dilakukan dengan menunjuk siswa secara acak sehingga setiap siswa mau tidak mau harus berpartisipasi aktif, siswa tidak bisa menghindar dari proses pembelajaran, setiap saat ia bisa dilibatkan dalam proses tanya jawab. Kemungkinan akan terjadi suasana tegang, namun demikian bisa dibiasakan. Untuk mengurangi kondisi tersebut, guru hendaknya memberikan serangkaian pertanyaan dengan wajah ramah, suara menyejukkan, nada lembut. Ada canda, senyum, dan ceria. Jangan lupa, bahwa jawaban siswa yang salah harus dihargai karena salah adalah cirinya dia sedang belajar, ia telah berpartisipasi.

Dalam model pembelajaran probing-prompting ini juga digunakan media pembelajaran. Media yang digunakan adalah media sederhana. Media sederhana ini memungkinkan adanya pemahaman secara langsung antara siswa dengan materi yang dipelajari. Media sederhana merupakan media atau benda tiruan yang menyerupai bentuk asli yang membantu pengalaman peserta didik dalam memahami materi pelajaran sehingga dapat mempermudah ketercapaian tujuan pembelajaran yang telah ditentukan. Dengan menggunakan media sederhana akan membantu mengembangkan kreatifitas serta aktivitas siswa dalam memahami materi. Menurut Sudarma dan Parmiti (dalam Sutrisna, 2012) media sederhana merupakan sarana pembelajaran yang dibuat dari bahan yang mudah didapatkan, mudah membuat, mudah digunakan, serta harganya relatif tidak mahal. Dengan demikian dapat dinyatakan bahwa model pembelajaran probing-prompting dengan berbantuan media sederhana dapat memberikan pengaruh yang positif terhadap hasil belajar siswa. Oleh karena itu model pembelajaran guru merupakan dasar untuk mencapai hasil belajar yang baik. Hasil belajar yang baik menunjukkan bahwa siswa memiliki pemahaman konsep terhadap suatu pelajaran.

Penelitian Hidayatullah (2014) menemukan bahwa penerapan model pembelajaran probingprompting berpengaruh terhadap kemampuan berpikir kritis siswa kelas V pada mata pelajaran IPA di Gugus Singasari Kecamatan Pekutatan tahun pelajaran 2013/2014. Kemudian hasil penelitian yang dilakukan oleh Swarjawa (2012) juga menunjukan adanya perbedaan yang signifikan dalam penelitiannya membuktikan bahwa penerapan model pembelajaran probing-prompting lebih berpengaruh baik terhadap hasil belajar IPA siswa dibandingkan dengan model pembelajaran konvensional.

Berdasarkan uraian tersebut, dipandang perlu dilakukan penelitian eksperimen dengan judul "Pengaruh Model Pembelajaran Probing-Prompting Berbantuan Media Sederhana Terhadap Hasil Belajar IPA Siswa Kelas III Semester II di SD Gugus III Kecamatan Banjar Kabupaten Buleleng Tahun Ajaran 2017/2018"

\section{Metode}

Penelitian ini merupakan jenis penelitian eksperimen semu (Quasi Experiment) karena tidak semua variabel muncul dalam kondisi eksperimen yang dapat diatur dan dikontrol secara ketat.. Rancangan kuasi eksperimen yang digunakan adalah non-equivalent post-test only control group design.

Dalam penelitian ini, yang diuji pengaruh antara siswa yang mendapat perlakuan model pembelajaran probing-prompting berbantuan media sederhana dan yang tidak mendapat perlakuan model pembelajaran probing-prompting berbantuan media sederhana terhadap hasil belajar IPA. 
Penelitian ini melibatkan kelompok kontrol sebagai pembanding kelompok eksperimen. Populasi dalam penelitian ini berjumlah tujuh kelas yaitu SD Negeri 1 Dencarik dengan jumlah 25 siswa, SD Negeri 2 Dencarik dengan jumlah 25 siswa, SD Negeri 3 Dencarik dengan jumlah 20 siswa, SD Negeri 1 Tampekan dengan jumlah 15 siswa, SD Negeri 1 Banjar Tegeha dengan jumlah 18 siswa, SD Negeri 3 Banjar Tegeha dengan jumlah 18 siswa, SD Negeri 3 Banjar Tegeha dengan jumlah 10 siswa, dan SD Negeri 4 Banjar dengan jumlah 17 siswa. Keseluruhan populasi adalah 130 siswa.

Dalam penelitian ini pengambilan sampel dilakukan dengan menggunakan teknik simple random sampling yaitu pemilihan sampel secara acak atau random. Teknik ini digunakan sebagai teknik pengambilan sampel karena individu-individu pada populasi telah terdistribusi ke dalam kelas-kelas sehingga tidak memungkinkan untuk melakukan pengacakkan terhadap individu-individu dalam populasi.

Tahap pertama dari tujuh sekolah yang ada di Gugus III Kecamatan Banjar Kabupaten Buleleng dilakukan pengundian untuk diambil dua kelompok yang dijadikan sampel penelitian. Kedua kelompok tersebut diundi lagi untuk menentukan kelompok eksperimen yang mendapat perlakuan model pembelajaran probing-prompting berbantuan media sederhana dan satu kelompok sebagai kelompok kontrol yang tidak mendapat perlakuan model pembelajaran probing-prompting berbantuan media sederhana atau pembelajaran berlangsung seperti biasanya yang dilakukan oleh guru. Berdasakan hasil pengundian untuk menentukan kelompok eksperimen dan kontrol, diperoleh kelas III SD Negeri 3 Dencarik sebagai kelompok eksperimen dengan perlakuan model pembelajaran probing-prompting berbantuan media sederhana, sedangkan kelompok kontrol diperoleh kelas III SD Negeri 2 Dencarik tanpa perlakuan model pembelajaran

Penelitian ini melibatkan dua variabel, yaitu model pembelajaran probing-prompting berbantuan media sederhana sebagai variabel bebas dan hasil belajar IPA sebagai variabel terikat. Pada kelas eksperimen akan diterapkan model pembelajaran probing-prompting berbantuan media sederhana, sedangkan pada kelas kontrol tidak menerapkan model pembelajaran probing-prompting berbantuan media sederhana. Pembelajaran dilakukan sebanyak 7 kali pertemuan dan satu kali post-test. Hasil belajar IPA diukur melalui post-test.

Data yang diperlukan dalam penelitian, yaitu data hasil belajar IPA. Bentuk tes hasil belajar yang digunakan berupa soal objektif (pilihan ganda). Pengumpulan data dalam penelitian ini mengunakan metode tes. Metode tes yang digunakan dalam penelitian ini adalah prosedur yang menggunakan sejumlah tes hasil belajar dalam bentuk objektif.

Instrumen yang digunakan untuk memperoleh data tentang hasil belajar IPA terdiri dari 30 soal. Setiap jawaban diberikan skor 1 jika menjawab benar dengan alasan yang tepat dan skor 0 jika tidak menjawab sama sekali. Skor setiap jawaban kemudian dijumlahkan dan jumlah tersebut merupakan skor hasil belajar siswa.

Metode analisis data yang digunakan dalam penelitian ini adalah metode analisis statistik deskriptif dan statistik inferensial (uji-t). Analisis deskriptif digunakan untuk mengetahui deskripsi hasil belajar IPA dengan mencari nilai mean, median, modus, standar deviasi, rentangan, dan varian. Selanjutnya, statistik inferensial digunakan untuk melakukan uji hipotesis. Sebelum uji hipotesis, dilakukan beberapa uji prasyarat berupa uji normalitas dan uji homogenitas, sedangkan metode analisis data yang digunakan untuk menguji hipotesis adalah analisis uji-t.

\section{Hasil dan Pembahasan}

Hasil analisis deskriptif data hasil belajar IPA pada kelompok eksperimen menunjukkan bahwa skor rata-rata adalah 22,6 dengan kategori sangat tinggi dan pengukuran hasil belajar IPA pada kelompok kontrol menunjukkan bahwa skor rata-rata adalah 18,64 dengan kategori tinggi. Rangkuman hasil deskripsi data hasil belajr IPA pada penelitian ini dapat dilihat pada Tabel 1.

Tabel 1. Rangkuman Deskrispsi Data Hasil Belajar IPA

\begin{tabular}{ccc}
\hline Statistik Deskriptif & \multicolumn{2}{c}{ Hasil Belajar IPA } \\
& Kelompok Eksperimen & Kelompok Kontrol \\
\hline Mean & 22,6 & 18,64 \\
Median & 23,5 & 18,4 \\
Modus & 25 & 16,75 \\
Varians & 21.85 & 17,64 \\
Standar Deviasi & 4,67 & 4,20 \\
Skor Maksimum & 29 & 27 \\
Skor Minimum & 12 & 12
\end{tabular}




\begin{tabular}{ccc}
\hline \multirow{2}{*}{ Statistik Deskriptif } & \multicolumn{2}{c}{ Hasil Belajar IPA } \\
& Kelompok Eksperimen & Kelompok Kontrol \\
\hline Rentangan & 17 & 15 \\
\hline
\end{tabular}

Berdasarkan hasil analisis despriptif pada Tabel 1 skor rata-rata hasil belajar IPA kelompok eksperimen lebih besar dibandingkan skor rata-rata hasil belajar IPA kelompok kontrol. Tinjauan ini didasarkan pada rata-rata skor dan kecenderungan skor hasil belajar IPA yang diperoleh kedua kelompok.

Pada kelompok eksperimen, rata-rata skor hasil belajar IPA pada kelompok eksperimen adalah 22,6 berada pada kategori sangat tinggi dan sebagain besar skor siswa cenderung tinggi. Gambaran data hasil belajar IPA pada kelompok kontrol dapat disajikan pada Gambar 1.

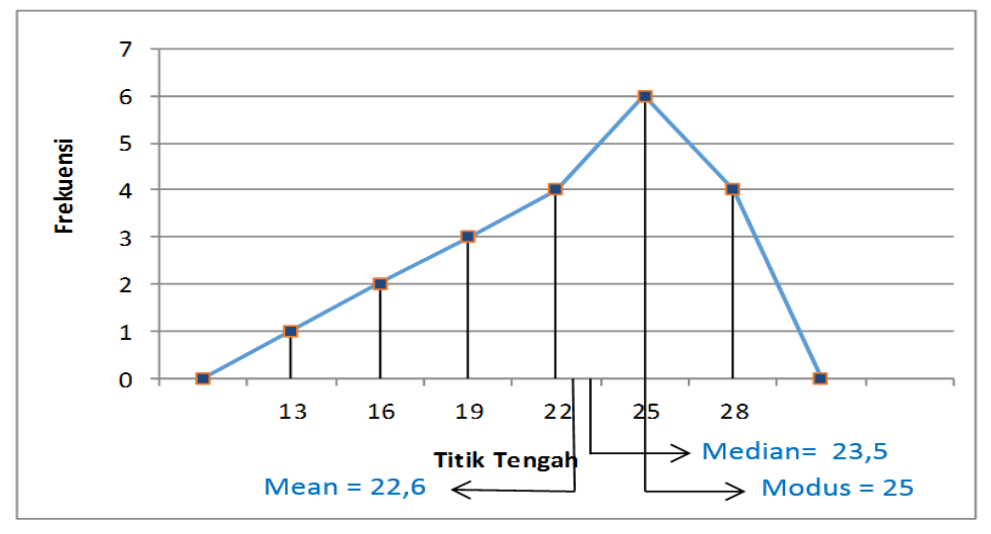

Gambar 1. Kurva Poligon Data Hasil Belajar IPA Kelompok Eksperimen

Pada kelompok kontrol, rata-rata skor hasil belajar IPA pada kelompok kontrol adalah 18,64 berada pada kategori tinggi dan sebagain besar skor siswa cenderung rendah. Gambaran data hasil belajar IPA pada kelompok kontrol dapat disajikan pada Gambar 2.

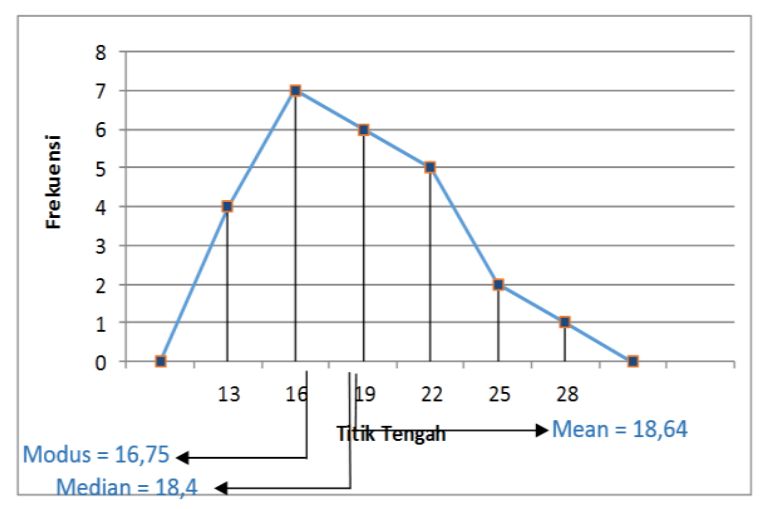

Gambar 2. Kurva Poligon Data Hasil Belajar IPA Kelompok Kontrol

Berdasarkan paparan tersebut, hasil belajar IPA pada kelompok eksperimen lebih baik daripada hasil belajar IPA pada kelompok kontrol. Hasil uji prasayat analisis menunjukkan data berdistribusi normal dan memiliki varians yang homogen.

Berdasarkan hasil uji hipotesis yang telah dilakukan, menunjukkan bahwa nilai $t_{\text {hitung }}=10,37$ sedangkan $t_{\text {tab }}$ dengan $\mathrm{dk}=20+25-2=43$ dan taraf signifikansi 5\% adalah 2,017. Hal ini berarti, $t_{\text {hit }}$ lebih besar dari $t_{\text {tab }}\left(t_{h i t}>t_{t a b}\right)$, sehingga hasilnya signifikan. Dengan demikian $\mathrm{H}_{1}$ diterima dan $\mathrm{H}_{0}$ ditolak, yang berarti terdapat pengaruh yang signifikan hasil belajar IPA antara siswa yang dibelajarkan dengan model pembelajaran probing-prompting berbantuan media sederhana dan siswa yang tidak dibelajarkan dengan model pembelajaran probing-prompting berbantuan media sederhana pada siswa kelas III SD Semester II Gugus III Kecamatan Banjar Tahun Pelajaran 2017/2018. Perhitungan uji hipotesis dilakukan dengan bantuan SPSS 20. 
Berdasarkan deskripsi data hasil penelitian menunjukkan bahwa terdapat pengaruh hasil belajar antara kelompok siswa yang diberikan perlakuan model pembelajaran probing-prompting berbantuan media sederhana dengan kelompok siswa yang tidak diberikan perlakuan model pembelajaran probingprompting berbantuan media sederhana. Secara deskriptif, hasil belajar IPA siswa kelompok eksperimen lebih tinggi dibandingkan dengan siswa kelompok kontrol. Tinjauan ini didasarkan pada rata-rata skor hasil belajar IPA dan kecenderungan skor hasil belajar IPA.

Perhitungan uji hipotesis menunjukan bahwa nilai signifikan Sig.(2 tailed) 0,003 0,05 maka $\mathrm{H}_{1}$ diterima dan $\mathrm{H}_{0}$ ditolak, sehingga dapat diartikan bahwa terdapat pengaruh yang signifikan hasil belajar IPA antara kelompok siswa kelas III yang diberi perlakuan dengan model pembelajaran probingprompting berbantuan media sederhana dan kelompok siswa yang tidak diberi perlakuan dengan model pembelajaran probing-prompting berbantuan media sederhana di Kelas III SD Gugus III Kecamatan Banjar Kabupaten Buleleng Tahun Pelajaran 2017/2018.

Pengaruh hasil belajar antara kelompok siswa yang diberikan perlakuan dengan model pembelajaran probing-prompting berbantuan media sederhana dengan kelompok siswa yang tidak diberikan perlakuan dengan model pembelajaran probing-prompting berbantuan media sederhana disebabkan adanya perbedaan perlakuan pada proses pembelajaran. Hal itu dikarenakan pada model pembelajaran probing-prompting berbantuan media sederhana siswa dilibatkan secara penuh dalam pembelajaran dan melatih sikap kesiapan siswa, meningkatkan kesopanan dan memberikan pengetahuan yang luas.

Peningkatan dapat terjadi karena beberapa hal. Pertama, pembelajaran yang menerapkan model pembelajaran probing-prompting berbantuan media sederhana dapat mengubah pembelajaran yang awalnya berpusat pada guru menjadi pembelajaran yang berpusat pada siswa. Siswa menjadi lebih termotivasi dan aktif dalam mengikuti pembelajaran. Dalam penerapan model pembelajaran probingprompting berbantuan media sederhana, siswa disuruh mengembangkan keberanian dan keterampilan dalam menjawab dan mengemukakan pendapat. Mereka aktif dalam menyampaikan maupun menjawab pertanyaan dari guru dan teman-temannya. Apabila siswa aktif dalam kegiatan pembelajaran maka berdampak pada meningkatnya motivasi belajar siswa, sehingga hasil belajar siswa pun dapat meningkat.

Suherman (dalam Huda, 2014:281) menyatakan bahwa, pembelajaran probing-prompting adalah pembelajaran dengan memberikan pertanyaan yang sifatnya menuntun dan menggali gagasan siswa sehingga dapat melejitkan proses berpikir yang mampu mengaitkan pengetahuan dengan pengalaman siswa dengan pengetahuan baru yang sedang dipelajari.

Shoimin (2014) mengemukakan kelebihan dari model pembelajaran probing-prompting diantaranya: a) Mendorong siswa aktif berpikir, b) Memberi kesempatan kepada siswa untuk menanyakan hal-hal yang kurang jelas, c) Perbedaan pendapat antara siswa dapat dikompromikan atau diarahkan, d) Sebagai cara meninjau kembali (review) bahan pelajaran yang lampau, e) Mengembangkan keberanian dan keterampilan siswa dalam menjawab dan mengemukakan pendapat, f) Pertanyaan dapat menarik dan memusatkan perhatian siswa.

Dalam model pembelajaran probing-prompting ini juga digunakan media pembelajaran. Media yang digunakan adalah media sederhana. Media sederhana ini memungkinkan adanya pemahaman secara langsung antara siswa dengan materi yang dipelajari. Media sederhana merupakan media atau benda tiruan yang menyerupai bentuk asli yang membantu pengalaman peserta didik dalam memahami materi pelajaran sehingga dapat mempermudah ketercapaian tujuan pembelajaran yang telah ditentukan. Dengan menggunakan media sederhana akan membantu mengembangkan kreatifitas serta aktivitas siswa dalam memahami materi. Menurut Sudarma dan Parmiti (dalam Sutrisna, 2012) media sederhana merupakan sarana pembelajaran yang dibuat dari bahan yang mudah didapatkan, mudah membuat, mudah digunakan, serta harganya relatif tidak mahal. Dengan demikian dapat dinyatakan bahwa model pembelajaran probing-prompting dengan berbantuan media sederhana dapat memberikan pengaruh yang positif terhadap hasil belajar siswa. Oleh karena itu model pembelajaran guru merupakan dasar untuk mencapai hasil belajar yang baik. Hasil belajar yang baik menunjukkan bahwa siswa memiliki pemahaman konsep terhadap suatu pelajaran. Sedangkan menurut Tegeh (dalam Suparini, 2012) media sederhana merupakan media yang mudah diperoleh dan harganya murah, cara pembuatannya mudah, dan penggunaannya tidak sulit. Dengan kesederhanaan dari media inilah diharapkan proses pembelajaran dapat mencapai hasil belajar yang maksimal.

Model pembelajaran probing-prompting berbantuan media sederhana sangat berbeda dengan model pembelajaran yang biasa diterapakan oleh guru-guru di sekolah. Perbedaan ini terlihat dari sintaks dan metode yang digunakan dalam proses pembelajaran. Model pembelajaran yang biasa dipakai oleh guru lebih cenderung guru yang aktif dalam proses pembelajaran, guru mentransfer begitu saja pengetahuan yang dimiliki kepada peserta didik tanpa memperhitungkan mental peserta didik. Kondisi 
seperti ini, mengakibatkan siswa pasif dalam pembelajaran di kelas dan cenderung akan cepat merasa bosan.

Berbeda halnya dengan model pembelajaran probing-prompting berbantuan media sederhana, dalam proses pembelajarannya siswa diberikan kesempatan untuk aktif dalam kegiatan pembelajaran melaui diskusi. Mulai dari kegiatan mengeksplorasi pengetahuan awal dan pengalaman siswa, melakukan diskusi kelompok untuk percobaan dan pengamatan, menjelaskan konsep dengan kalimat sendiri, menerapkan konsep dengan tes tertulis, dan merangkum proses pembelajaran yang telah dilaksanakan. Proses pembelajaran seperti inilah yang diinginkan oleh peserta didik, mereka diberikan kebebasan untuk mengeksplor kemampuan yang mereka miliki.

Penelitian yang sejenis dilakukan oleh Hidayatullah (2014) yaitu dengan hasil bahwa terdapat perbedaan yang signifikan kemampuan berpikir kritis antara kelompok siswa yang belajar dengan menggunakan model pembelajaran probing-prompting dan kelompok siswa yang belajar dengan menggunakan model pembelajaran Konvensional. Penelitian yang dilakukan oleh Swarjawa (2013) yang menemukan bahwa pembelajaran probing-prompting dapat meningkatkan prestasi belajar siswa. Penelitian yang dilakukan oleh Widyastuti (2014) yang menemukan pembelajaran probing-prompting dapat meningkatkan prestasi belajar siswa. Berdasarkan beberapa kajian relevan diatas dapat disentesiskan bahwa model pembelajaran probing-prompting berbantuan media sederhana dapat meningkatkan hasil belajar siswa.

\section{Simpulan dan Saran}

Berdasarkan hasil pengujian hipotesis dan pembahasan, maka simpulan penelitian ini yaitu terdapat pengaruh hasil belajar pada kelompok siswa yang diberikan perlakuan model pembelajaran probing-prompting berbantuan media sederhana dengan kelompok siswa yang tidak diberikan perlakuan model pembelajaran probing-prompting berbantuan media sederhana dalam pembelajaran IPA pada siswa kelas III semester II Kecamatan Banjar Tahun Pelajaran 2017/2018. Rata-rata skor hasil belajar IPA kelompok siswa yang dibelajarkan menggunakan model pembelajaran probing-prompting berbantuan media sederhana adalah 22,6 sedangkan rata-rata skor kelompok siswa yang dibelajarkan tanpa menggunakan model pemebelajaran probing-prompting adalah 18,64. Dengan demikian model pembelajaran probing-prompting berbantuan media sederhana memiliki pengaruh terhadap hasil belajar.

Saran yang dapat disampaikan berdasarkan penelitian yang telah dilakukan adalah sebagai berikut. 1) Disarankan kepada peserta didik agar lebih berani dalam mengemukakan pendapat dan aktif dalam proses pembelajaran untuk dapat mengembangkan pemikirannya khususnya dalam pembelajaran IPA melalui penerapan model pembelajaran probing-prompting berbantuan media sederhana sehingga mampu meningkatkan hasil belajar secara maksimal. 2) Disarankan kepada para guru agar menggunakan model pembelajaran probing-prompting berbantuan media sederhana khususnya dalam mata pelajaran IPA dan mata pelajaran lain pada umumnya dalam upaya meningkatkan hasil belajar siswa. 3) Disarankan kepada kepala sekolah agar membina para guru dalam memilih dan menerapkan model pembelajaran yang tepat salah satunya dapat menggunakan model pembelajaran pobing-prompting berbantuan media sederhana seperti yang telah dilakukan dalam penelitian ini dengan hasil penelitian yang menunjukan perbedaan rata-rata hasil belajar IPA yang lebih baik dibandingkan dengan yang tidak menggunakan model pembelajaran pobing-prompting berbantuan media sederhana. 4) Disarankan kepada peneliti lain yang berminat untuk mengadakan penelitian lebih lanjut tentang model pembelajaran probing-prompting berbantuan media sederhana dalam bidang Ilmu Pengetahuan Alam maupun bidang ilmu lainnya yang sesuai agar memperhatikan kendala-kendala yang dialami dalam penelitian ini sebagai bahan pertimbangan untuk perbaikan dan penyempurnaan penelitian yang akan dilaksanakan.

\section{Daftar Rujukan}

Artawan, Ketut Agus, I Ketut Gading, I Ketut Dibia. 2017. Pengaruh Model Pembelajaran Probing Prompting Terhadap Hasil Belajar Ipa Pada Siswa Kelas V SD. e-Journal PGSD Universitas Pendidikan Ganesha Mimbar PGSD Vol. 5 No. 2.

Hanggara, Yudhi, Vina Alfionita. 2015. Eksperimentasi Model Pembelajaran Probing Prompting Dan Discovery Learning Terhadap Hasil Belajar Matematika Ditinjau Dari Minat Belajar Siswa Kelas Vii Smp Negeri 3 Batam. PYTHAGORAS, 4(2): 1-11

Hidayatullah, Patunda Al Arif. 2014. Pengaruh Model Probing-prompting Terhadap Kemampuan Berpikir Kritis Siswa Pada Mata Pelajaran IPA kelas V. MIMBAR PGSD Universitas Pendidikan Ganesha 
Jurusan PGSD Volume 2 Nomor 1 (hlm 1). Tersedia Pada (ejournal.undiksha.ac.id/index.php/JJPGSD/article/.../3560/2876). diakses tanggal 9 Januari 2018.

Huda, Miftahul. 2014. Model-Model Pengajaran dan Pembelajaran Isu-isu Metodis dan Paradigmatis. Yogyakarta: Pustaka Pelajar.

Kariani, Ni Kd., Putra, S., \& Ardana, I Kt. (2014). Model Problem Based Learning Menggunakan Metode Probing-Prompting Berpengaruh Terhadap Hasil Belajar IPA Siswa. Jurnal Mimbar PGSD Universitas Pendidikan Ganesha Jurusan PGSD, 2 (1).

Ngalimun, dkk. 2016. Strategi dan Model Pembelajaran. Yogyakarta: Aswaja Pressindo.

Riastini, Putu Nanci. 2016. Pembelajaran IPA SD. Singaraja: Undiksha Press.

Safitri, Aprilia, Solihin Ichas H , Titing Rohayati. 2015. Penerapan Probing - Prompting Untuk Meningkatkan Kemampuan Berpikir Kritis Siswa Pada Pembelajaran Ips Di Sd. Antologi UPI, Volume 3 Nomor 2

Shoimin, Aris. 2014. 68 Model Pembelajaran Inovatif Dalam Kurikulum 2013. Yogyakarta: AR-RUZZ MEDIA.

Sudana, Dewa Nyoman \& dkk. 2016. Pendidikan IPA SD. Singaraja: Universitas Pendidikan Ganesha.

Sukardjo, M dan Ukim Komarudin. 2012. Landasan Pendidikan Konsep dan Aplikasinya. Jakarta: PT Raja Grafindo Persada.

Suparini, 2012. "Pengaruh Model Pembelajaran Heuristik VEE Berbantuan Media Sederhana Terhadap Hasil Belajar Siswa Kelas V SD Negeri 8 Banjar Anyar”. Tersedia pada (http://id.portalgaruda.org/index.php?ref=browse\&mod=viewarticle\&article=105459) diakses tanggal 14 Januari 2018

Susanto, Ahmad. 2013. Teori Belajar \& Pembelajaran di Sekolah Dasar. Jakarta: Kencana Prenadamedia Group.

Sutrisna, 2012. "Pengaruh Model Pembelajaran Koperatif Tipe STAD Berbantuan Media Sederhana Terhadap Hasil Belajar IPA Siswa Pada Kelas IV SD Negeri 1 Pangkungparuk". (http://id.portalgaruda.org/index.php?ref=browse\&mod=viewarticle\&article=105486) diakses tanggal 14 Januari 2018.

Swarjawa, 2012. "Pengaruh Model Pembelajaran Probing-Prompting Terhadap Hasil Belajar IPA Siswa Kelas V DI SD Negeri 1 Sebatu". Tersedia pada (http://id.portalgaruda.org/index.php?ref=browse\&mod=viewarticle\&article=105456) diakses tanggal 14 Januari 2018.

Undang-Undang No. 20 Tahun 2003 tentang Sistem Pendidikan Nasional. 2003. Departemen Pendidikan Nasional.

Widyastuti, Dyah Ayu. 2014. "Penerapan Model Pembelajaran Probing-prompting Untuk Meningkatkan Prestasi Belajar IPA Siswa Kelas IV SD Negeri 2 Antosari Kecamatan Selemadeg Barat”. MIMBAR PGSD Universitas Pendidikan Ganesha, Volume 2 No. 1 (hlm 1). Tersedia Pada (http://id.portalgaruda.org/index.php?ref=browse\&mod=viewarticle\&article=304402). diakses tanggal 17 Januari 2018. 